Article

\title{
Low-Temperature Molten Salt Synthesis and the Characterisation of Submicron-Sized $\mathrm{Al}_{8} \mathrm{~B}_{4} \mathrm{C}_{7}$ Powder
}

\author{
Cheng Liu ${ }^{1}\left(\mathbb{D}\right.$, Xueyin Liu $^{2}$, Zhaoping Hou ${ }^{3} \mathbb{D}$, Quanli Jia $\left.{ }^{4} \mathbb{(}\right)$, Benjun Cheng ${ }^{5, *}$ and \\ Shaowei Zhang ${ }^{1, *}$ \\ 1 College of Engineering, Mathematics and Physical Sciences, University of Exeter, Exeter EX4 4QF, UK; \\ c1445@exeter.ac.uk \\ 2 The State Key Laboratory of Refractories and Metallurgy, Wuhan University of Science and Technology, \\ Wuhan 430081, China; kklldliu@163.com \\ 3 College of Materials Science and Engineering, Taiyuan University of Technology, Taiyuan 030024, China; \\ houzhaoping@tyut.edu.cn \\ 4 Henan Key Laboratory of High Temperature Functional Ceramics, Zhengzhou University, \\ Zhengzhou 450052, China; jiaquanli@zzu.edu.cn \\ 5 School of Energy Science and Engineering, Central South University, Changsha 410205, China \\ * Correspondence: chbj666@mail.csu.edu.cn (B.C.); s.zhang@exeter.ac.uk (S.Z.)
}

Received: 2 December 2019; Accepted: 18 December 2019; Published: 22 December 2019

\begin{abstract}
Submicron-sized ( $200 \mathrm{~nm})$ aluminium boron carbide $\left(\mathrm{Al}_{8} \mathrm{~B}_{4} \mathrm{C}_{7}\right)$ particles were synthesised from $\mathrm{Al}, \mathrm{B}_{4} \mathrm{C}$ and carbon black raw materials in a molten $\mathrm{NaCl}$-based salt at a relatively low temperature. The effects of the salt type/assembly and the firing temperature on the synthesis process were examined, and the relevant reaction mechanisms discussed. The molten salt played an important role in the $\mathrm{Al}_{8} \mathrm{~B}_{4} \mathrm{C}_{7}$ formation process. By using a combined salt of $95 \% \mathrm{NaCl}+5 \% \mathrm{NaF}$, an effective liquid reaction medium was formed, greatly facilitating the $\mathrm{Al}_{8} \mathrm{~B}_{4} \mathrm{C}_{7}$ formation. As a result, essentially phase-pure $\mathrm{Al}_{8} \mathrm{~B}_{4} \mathrm{C}_{7}$ was obtained after $6 \mathrm{~h}$ of firing at $1250{ }^{\circ} \mathrm{C}$. This temperature was $350-550{ }^{\circ} \mathrm{C}$ lower than that required by the conventional direct reaction and thermal reduction methods.
\end{abstract}

Keywords: $\mathrm{Al}_{8} \mathrm{~B}_{4} \mathrm{C}_{7}$; molten salt synthesis; low temperature; carbon black; $\mathrm{B}_{4} \mathrm{C}$

\section{Introduction}

Like their binary counterparts, ternary carbides are also an important class of high-performance non-oxide ceramics that have attracted great research interest, especially during the past decade. Among them, aluminium boron carbide $\left(\mathrm{Al}_{8} \mathrm{~B}_{4} \mathrm{C}_{7}\right.$ or $\left.\mathrm{Al}_{3} \mathrm{BC}_{3}\right)$ is regarded as a promising candidate material potentially applicable to a variety of important areas, such as high-temperature structural ceramics, as an antioxidant for carbon-containing refractories [1-5], as a sintering agent for $\mathrm{SiC}$, $\mathrm{ZrB}_{2}$ and $\mathrm{B}_{4} \mathrm{C}$ materials [6-10], and as an absorber for new-generation nuclear reactors [11]. This is because of its many superior properties, including high hardness (15.2 GPa), high melting point $\left(190{ }^{\circ} \mathrm{C}\right)$, relatively low density $\left(2.69 \mathrm{~g} / \mathrm{cm}^{3}\right)$ and low thermal expansion coefficient $\left(6.67 \times 10^{-6} / \mathrm{K}\right)$, high thermal conductivity $(29.2 \mathrm{~W} / \mathrm{m} / \mathrm{K})$, and good oxidation/corrosion resistance [1,12-14].

To fabricate high-performance $\mathrm{Al}_{8} \mathrm{~B}_{4} \mathrm{C}_{7}$-based bulk ceramics, high-quality $\mathrm{Al}_{8} \mathrm{~B}_{4} \mathrm{C}_{7}$ powder often needs to be used. In this regard, several synthesis methods/techniques have been developed to date, among which the thermal reduction and direct reaction methods have been investigated most extensively. In the former, $\mathrm{Al}$ or carbon $(\mathrm{C})$ is often used as a reducing agent [15-18], so inexpensive and readily available boron-containing oxides can be used as a boron source to replace the much more expensive element boron (B) or $\mathrm{B}_{4} \mathrm{C}$. However, a high synthesis temperature $\left(1700-1800^{\circ} \mathrm{C}\right)$ is required to complete the formation reaction. Furthermore, some by-products/intermediate phases such as 
$\mathrm{Al}_{2} \mathrm{O}_{3}, \mathrm{Al}_{4} \mathrm{O}_{4} \mathrm{C}$ and $\mathrm{Al}_{2} \mathrm{OC}$ often remain in the final product powder. In addition, the product particles generally have relatively large sizes and suffer from heavy agglomeration. For example, $\mathrm{Zhu}$ et al. [15] and Deng et al. [16] prepared $\mathrm{Al}_{8} \mathrm{~B}_{4} \mathrm{C}_{7}$ powder containing secondary phases of $\mathrm{Al}_{2} \mathrm{O}_{3}, \mathrm{Al}_{2} \mathrm{OC}$ and $\mathrm{Al}_{4} \mathrm{O}_{4} \mathrm{C}$ at $1700{ }^{\circ} \mathrm{C}$ by using $\mathrm{B}_{2} \mathrm{O}_{3}$ (or $\mathrm{Na}_{2} \mathrm{~B}_{4} \mathrm{O}_{7} \cdot 10 \mathrm{H}_{2} \mathrm{O}$ ), $\mathrm{Al}$ and $\mathrm{C}$ as raw materials. By using similar raw materials and a higher temperature $\left(1800^{\circ} \mathrm{C}\right)$, Cui et al. [17] prepared hexagonal micro-platelets of $\mathrm{Al}_{8} \mathrm{~B}_{4} \mathrm{C}_{7}$ containing minor $\mathrm{Al}_{2} \mathrm{OC}$. On the other hand, Lee et al. [18] prepared $\mathrm{Al}_{3} \mathrm{BC}_{3}$ via a complex route using $\mathrm{Al}(\mathrm{OH})_{3}, \mathrm{~B}_{2} \mathrm{O}_{3}$ and phenolic resin as raw materials. Despite the use of phenolic resin instead of solid C powder, the synthesis temperature still remained as high as $1725^{\circ} \mathrm{C}$.

In contrast to the thermal reduction method, no reducing agent is required for the direct reaction method. The raw material assemblies commonly used by this method include: (1) $\mathrm{Al}_{4} \mathrm{C}_{3}$ and $\mathrm{B}_{4} \mathrm{C}$; (2) $\mathrm{Al}, \mathrm{B}$ and $\mathrm{C}$; and (3) $\mathrm{Al}, \mathrm{B}_{4} \mathrm{C}$ and C. Unfortunately, this method also suffers from similar drawbacks to those of the thermal reduction method, i.e., high synthesis temperature $\left(1600-1800^{\circ} \mathrm{C}\right)[11,13,14,19-21]$, and relatively large sizes of product particles with heavy agglomeration among them. For example, Inoue et al. [22] synthesised $\mathrm{Al}_{8} \mathrm{~B}_{4} \mathrm{C}_{7}$ powder via a respectively direct solid-solid reaction between $\mathrm{Al}_{4} \mathrm{C}_{3}$ and $\mathrm{B}_{4} \mathrm{C}$ at $1800{ }^{\circ} \mathrm{C}$, and double stage reactions between $\mathrm{Al}, \mathrm{B}$ and $\mathrm{C}$ initially at $1400{ }^{\circ} \mathrm{C}$ and then at $1830^{\circ} \mathrm{C}$. Several other researchers, e.g., Gao et al. [21], Hashimoto et al. [14] and Wang et al. [13], also synthesised $\mathrm{Al}_{8} \mathrm{~B}_{4} \mathrm{C}_{7}$ powder at $1600-1800{ }^{\circ} \mathrm{C}$ by using $\mathrm{Al}, \mathrm{B}_{4} \mathrm{C}$ and $\mathrm{C}$ as raw materials.

To overcome the drawbacks of the two main synthesis techniques stated above, it is necessary to develop alternative techniques. As a response to this, in the present work, a molten salt synthesis (MSS) method, used previously to prepare oxide and binary carbide powders [23-25], was further developed and extended to synthesise high-quality submicron-sized $\mathrm{Al}_{8} \mathrm{~B}_{4} \mathrm{C}_{7}$ powder at a much lower temperature, from $\mathrm{Al}, \mathrm{B}_{4} \mathrm{C}$ and $\mathrm{C}$ starting materials. As-prepared $\mathrm{Al}_{8} \mathrm{~B}_{4} \mathrm{C}_{7}$ powder was characterised, and the effects of key processing factors such as firing temperature and salt type/assembly on MSS were investigated. Based on the experimental results, the synthesis/formation mechanism of $\mathrm{Al}_{8} \mathrm{~B}_{4} \mathrm{C}_{7}$ was discussed.

\section{Experimental Procedure}

\subsection{Raw Materials}

$\mathrm{Al}$ (99.7\% pure, $<25$ micron), $\mathrm{B}_{4} \mathrm{C}$ (99.98\% pure), amorphous B (95\% pure) and C (carbon black, $\geq 99 \%$ pure, $<250 \mathrm{~nm})$ powders were used as raw materials, and $\mathrm{NaCl}(\geq 99 \%)$ and $\mathrm{NaF}(\geq 98 \%)$ were used to form the desired liquid reaction medium. They were all purchased from Sigma-Aldrich (Gillingham, UK).

\subsection{Sample Preparation}

$\mathrm{Al}, \mathrm{B}_{4} \mathrm{C}$ and $\mathrm{C}$ were mixed in the stoichiometric molar ratios of 8:1:6 (1.35:0.35:0.53 $\mathrm{g}$ in a powder batch) corresponding to Equation (1), and then they were further combined with $20 \mathrm{~g}$ binary salt of $95 \% \mathrm{NaCl}+5 \% \mathrm{NaF}$ in an agate mortar. The mixed powder batch was contained in a graphite crucible covered with a graphite lid, and then it was placed in an alumina tube furnace protected by flowing argon (Ar). The furnace was heated to a target temperature between 1100 and $1250{ }^{\circ} \mathrm{C}\left(\right.$ at $5{ }^{\circ} \mathrm{C} / \mathrm{min}$ to $1000{ }^{\circ} \mathrm{C}$, then $3^{\circ} \mathrm{C} / \mathrm{min}$ to $1200^{\circ} \mathrm{C}$ and finally $1^{\circ} \mathrm{C} / \mathrm{min}$ to the target temperature) and held at the temperature for $6 \mathrm{~h}$.

$$
8 \mathrm{Al}+\mathrm{B}_{4} \mathrm{C}+6 \mathrm{C}=\mathrm{Al}_{8} \mathrm{~B}_{4} \mathrm{C}_{7}
$$

To study the effects of salt type/assembly on the formation of $\mathrm{Al}_{8} \mathrm{~B}_{4} \mathrm{C}_{7}$, two other types of salts $(\mathrm{NaCl}$, and $97.5 \% \mathrm{NaCl}+2.5 \% \mathrm{NaF})$ were used, as well as the binary salt $\mathrm{NaCl}-\mathrm{NaF}$ stated above, to form the reaction media. They were then compared.

In addition, to assist in clarifying the relevant reaction/formation mechanisms, the following supplementary experiment was also carried out, and the resultant samples were similarly characterised (Section 2.3 below). In the first test, $\mathrm{Al}$ and $\mathrm{B}_{4} \mathrm{C}(1.35$ and $0.35 \mathrm{~g})$ in the molar ratio of 8:1 (referred to as $\mathrm{Al}-\mathrm{B}_{4} \mathrm{C}$ sample) were heated in $20 \mathrm{~g}$ of $95 \% \mathrm{NaCl}+5 \% \mathrm{NaF}$ at $1250{ }^{\circ} \mathrm{C}$ for $6 \mathrm{~h}$. The reacted mass was 
further combined with $0.53 \mathrm{~g} \mathrm{C}$ (so the molar ratio of $\mathrm{Al}: \mathrm{B}_{4} \mathrm{C}: \mathrm{C}=8: 1: 6$ ) and reheated at $1250{ }^{\circ} \mathrm{C}$ for $6 \mathrm{~h}$ in the identical salt. In the second test, $\mathrm{Al}_{4} \mathrm{C}_{3}$ (prepared via the reaction of stoichiometric amounts of $\mathrm{Al}$ and $\mathrm{C}$ in $20 \mathrm{~g}$ of $95 \% \mathrm{NaCl}+5 \% \mathrm{NaF}$ at $1150{ }^{\circ} \mathrm{C}$ for $6 \mathrm{~h}$ ) was combined with $\mathrm{B}$ and $\mathrm{C}$ (the molar ratio of $\mathrm{Al} / \mathrm{B}_{4} \mathrm{C} / \mathrm{C}=8: 1: 6$ ) (referred to as $\mathrm{Al}_{4} \mathrm{C}_{3}-\mathrm{B}-\mathrm{C}$ sample) and fired at $1250{ }^{\circ} \mathrm{C}$ for $6 \mathrm{~h}$.

Some of the samples after firing were placed immediately in a desiccator to avoid the hydration of $\mathrm{Al}_{4} \mathrm{C}_{3}$ in them prior to characterisation, whereas the other fired samples were subjected to repeated hot water washing to leach out the residual salt, followed by overnight oven-drying at $100{ }^{\circ} \mathrm{C}$.

\subsection{Sample Characterisation}

Phases in fired samples were identified by powder X-ray diffraction (XRD) analysis (Bruker D8 advance reflection diffractometer, Karlsruhe, Germany). The diffractometer was operated at $40 \mathrm{~mA}$ and $40 \mathrm{kV}$ using Ni-filtered CuKa radiation. The scan rate was $2.4^{\circ}(2 \theta) / \mathrm{min}$ with a step size of $0.04^{\circ}$. The ICDD cards used for identification were $\mathrm{Al}_{8} \mathrm{~B}_{4} \mathrm{C}_{7}$ (35-1216), $\mathrm{Al}_{3} \mathrm{BC}_{3}$ (88-1267), $\mathrm{Al}_{4} \mathrm{C}_{3}$ (35-0799), $\mathrm{AlOOH}$ (21-1307), $\mathrm{Al}$ (65-2869), $\mathrm{Al}_{2} \mathrm{O}_{3}$ (46-1212), $\mathrm{Al}_{3} \mathrm{BC}$ (50-1470), $\mathrm{AlB}_{2}$ (65-9698) and NaCl (05-0628). The microstructure and morphology of the as-prepared product powder were observed using a scanning electron microscope (SEM Nova Nanolab 600, FEI Company, Hillsboro, OR, USA) and a JEM 2100 transmission electron microscope (TEM, $200 \mathrm{kV}$ ).

\section{Results and Preliminary Discussion}

\subsection{Effect of Firing Temperature on the Formation of $A l_{8} B_{4} C_{7}$}

Figures 1 and 2 show XRD patterns of samples resulting from $6 \mathrm{~h}$ of firing at different temperatures in $95 \% \mathrm{NaCl}+5 \% \mathrm{NaF}$, before and after water washing, respectively. The formation of $\mathrm{Al}_{8} \mathrm{~B}_{4} \mathrm{C}_{7}$ was already evident after $6 \mathrm{~h}$ at $1100{ }^{\circ} \mathrm{C}$, but the intermediate phase of $\mathrm{Al}_{4} \mathrm{C}_{3}$ was also detected (Figure 1a). With an increase in temperature to 1150 and then $1200{ }^{\circ} \mathrm{C}, \mathrm{Al}_{8} \mathrm{~B}_{4} \mathrm{C}_{7}$ increased, whereas $\mathrm{Al}_{4} \mathrm{C}_{3}$ decreased (Figure $1 \mathrm{~b}, \mathrm{c}$ ). Upon increasing the temperature to $1250{ }^{\circ} \mathrm{C}, \mathrm{Al}_{4} \mathrm{C}_{3}$ disappeared, and only $\mathrm{Al}_{8} \mathrm{~B}_{4} \mathrm{C}_{7}$ was identified (though a minor peak from an unknown phase appeared at $2 \theta=23.3^{\circ}$ ), i.e., essentially phase-pure $\mathrm{Al}_{8} \mathrm{~B}_{4} \mathrm{C}_{7}$ was formed (Figure $1 \mathrm{~d}$ ). $\mathrm{AlOOH}$ was detected in some of the washed samples (Figure $2 \mathrm{a}-\mathrm{c}$ ) due to the partial hydration of $\mathrm{Al}_{4} \mathrm{C}_{3}$ in the original fired samples (Figure $1 \mathrm{a}-\mathrm{C}$ ) during the repeated water-washing process (Equation (2)). As shown in Figure 2, $\mathrm{AlOOH}$, i.e., $\mathrm{Al}_{4} \mathrm{C}_{3}$, decreased with the increase in the corresponding firing temperature. It disappeared upon increasing the firing temperature to $1250{ }^{\circ} \mathrm{C}$, verifying the completion of the formation reaction at this temperature (Figure 2d).

$$
\mathrm{Al}_{4} \mathrm{C}_{3}+8 \mathrm{H}_{2} \mathrm{O}=4 \mathrm{AlOOH}+3 \mathrm{CH}_{4}
$$




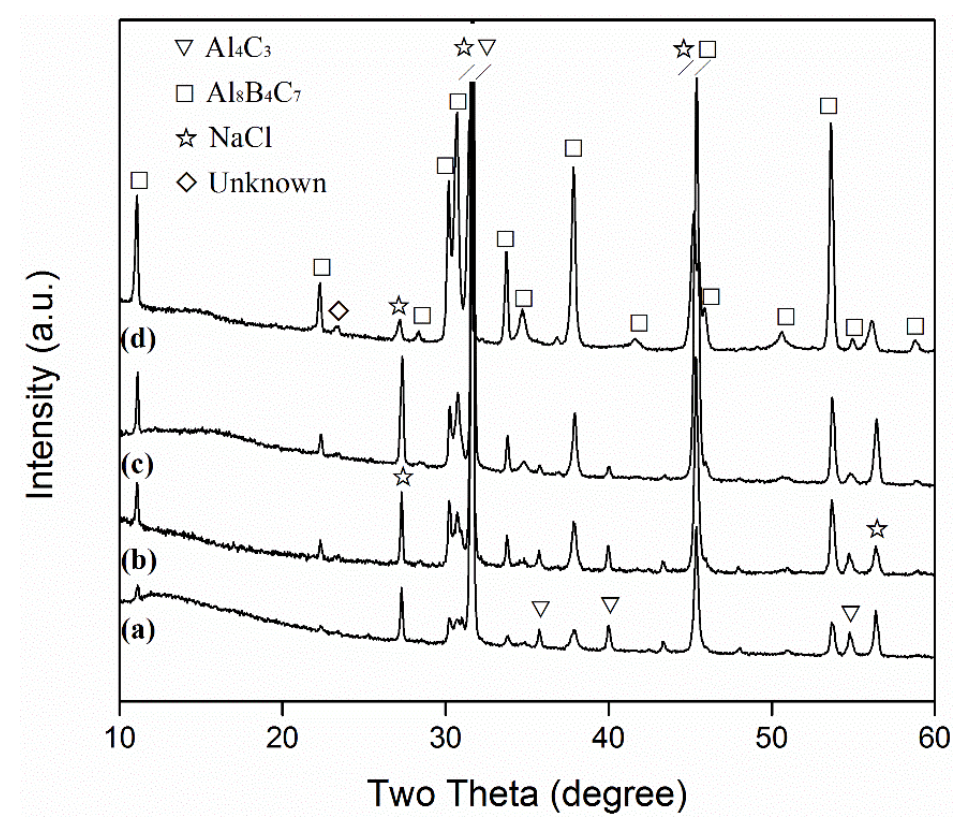

Figure 1. X-ray diffraction (XRD) patterns of samples resulting from $6 \mathrm{~h}$ of firing in $95 \% \mathrm{NaCl}+5 \% \mathrm{NaF}$ salt at: (a) 1100, (b) 1150, (c) 1200, and (d) $1250^{\circ} \mathrm{C}$, respectively (prior to water washing).

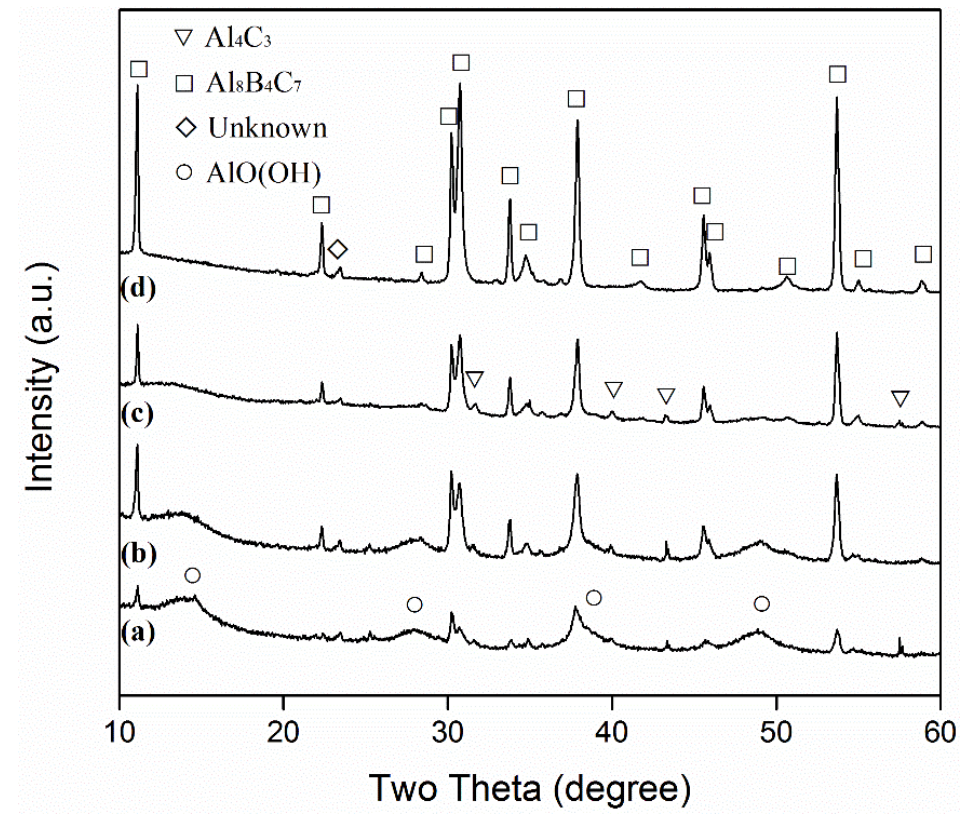

Figure 2. XRD patterns of samples resulting from 6 h of firing at: (a) 1100, (b) 1150, (c) 1200, and (d) $1250{ }^{\circ} \mathrm{C}$, respectively (after water washing).

\subsection{Supplementary Experiment for Mechanism Clarification}

Shown in Figure 3 are the XRD patterns of the Al- $\mathrm{B}_{4} \mathrm{C}$ sample after the first-stage firing, and the patterns after subsequent re-firing with $\mathrm{C}$ in the $95 \% \mathrm{NaCl}+5 \% \mathrm{NaF}$ salt. After the first-stage firing (Figure $3 \mathrm{a}$ ), $\mathrm{Al}_{3} \mathrm{BC}$ was formed as the main phase, along with some $\mathrm{AlB}_{2}$. However, after the second-stage firing with $\mathrm{C}, \mathrm{Al}_{8} \mathrm{~B}_{4} \mathrm{C}_{7}$ became the primary phase (Figure $3 \mathrm{~b}$ ), suggesting that the $\mathrm{Al}_{3} \mathrm{BC}$ that formed in the sample after the first-stage firing was converted into $\mathrm{Al}_{8} \mathrm{~B}_{4} \mathrm{C}_{7}$. Figure 4 further presents the XRD pattern of the $\mathrm{Al}_{4} \mathrm{C}_{3}$-B-C sample after $6 \mathrm{~h}$ of firing in the $95 \% \mathrm{NaCl}+5 \% \mathrm{NaF}$ salt at $1250{ }^{\circ} \mathrm{C}$, revealing the formation of the primary phase of $\mathrm{Al}_{8} \mathrm{~B}_{4} \mathrm{C}_{7}$, as well as minor residual $\mathrm{C}$ and $\mathrm{Al}_{2} \mathrm{O}_{3}$. The minor $\mathrm{Al}_{2} \mathrm{O}_{3}$ detected in this case (also in Figure $3 \mathrm{~b}$ ) was likely a result of the decomposition 
of $\mathrm{AlOOH}$ formed from the quick hydration of $\mathrm{Al}_{4} \mathrm{C}_{3}$ by the moisture in the atmosphere during the sample processing.

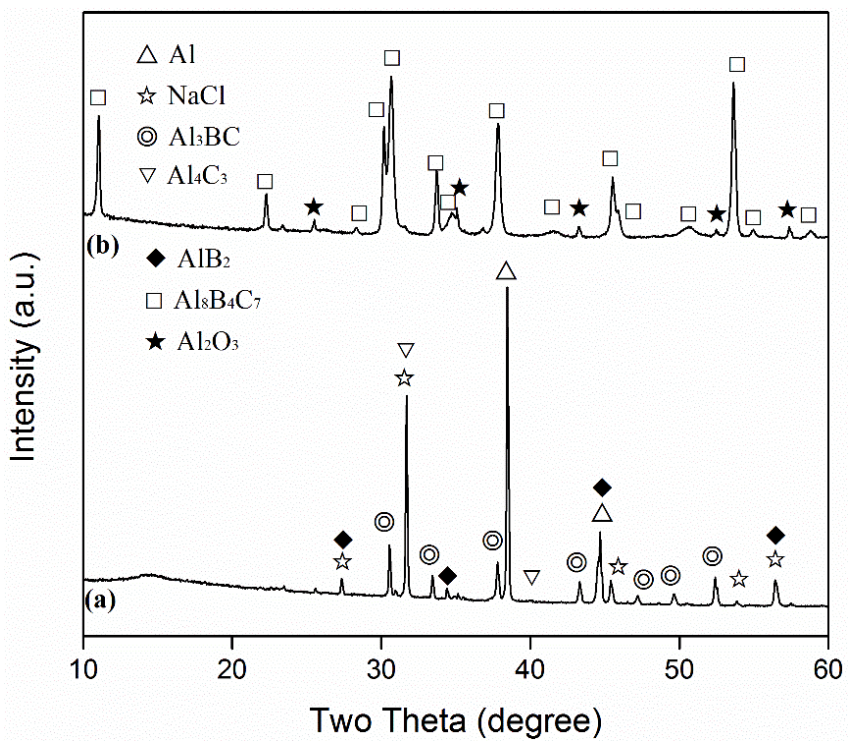

Figure 3. XRD patterns of: (a) the $\mathrm{Al}-\mathrm{B}_{4} \mathrm{C}$ sample after $6 \mathrm{~h}$ of firing in $95 \% \mathrm{NaCl}+5 \% \mathrm{NaF}$ at $1250{ }^{\circ} \mathrm{C}$, and (b) the sample resulting from further firing of (a) with $\mathrm{C}$ in $95 \% \mathrm{NaCl}+5 \% \mathrm{NaF}$ at $1250{ }^{\circ} \mathrm{C}$ for $6 \mathrm{~h}$.

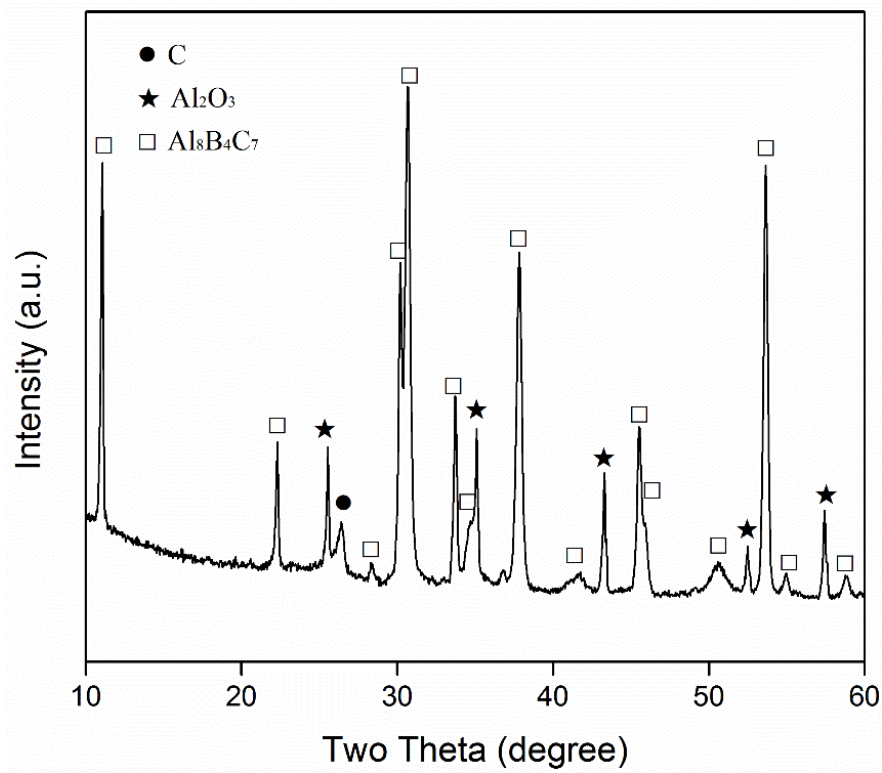

Figure 4. XRD pattern of the $\mathrm{Al}_{4} \mathrm{C}_{3}-\mathrm{B}-\mathrm{C}$ sample after $6 \mathrm{~h}$ of firing in $95 \% \mathrm{NaCl}+5 \% \mathrm{NaF}$ at $1250{ }^{\circ} \mathrm{C}$.

\subsection{Effect of Salt Type/Assembly on the Formation of $A l_{8} B_{4} C_{7}$}

Figure 5 demonstrates the effect of salt type/assembly on the $\mathrm{Al}_{8} \mathrm{~B}_{4} \mathrm{C}_{7}$ formation. In the case of using $\mathrm{NaCl}$ (Figure 5a), only minor $\mathrm{Al}_{8} \mathrm{~B}_{4} \mathrm{C}_{7}$ was formed, but large amounts of $\mathrm{AlOOH}$ were detected in the water-washed sample, indicating the presence of large amounts of intermediate $\mathrm{Al}_{4} \mathrm{C}_{3}$ in the original fired sample. This implied the limited accelerating effect of $\mathrm{NaCl}$ on the $\mathrm{Al}_{8} \mathrm{~B}_{4} \mathrm{C}_{7}$ formation. However, when small amounts ( 0.5 g, i.e., $2.5 \%)$ of $\mathrm{NaF}$ were combined with $\mathrm{NaCl}, \mathrm{Al}_{8} \mathrm{~B}_{4} \mathrm{C}_{7}$ became the main phase, although some $\mathrm{AlOOH}$ (i.e., $\mathrm{Al}_{4} \mathrm{C}_{3}$ in the original fired sample) was still detected (Figure $5 b$ ). This indicated the great accelerating effect of the NaF addition on the overall synthesis process. Upon further increasing the $\mathrm{NaF}$ amount to $1 \mathrm{~g}$ (i.e., $5 \%$ ), $\mathrm{AlOOH}$ (i.e., $\mathrm{Al}_{4} \mathrm{C}_{3}$ ) disappeared and 
essentially phase-pure $\mathrm{Al}_{8} \mathrm{~B}_{4} \mathrm{C}_{7}$ was formed (Figure $5 \mathrm{c}$ ). The above results indicated that the optimal salt type/assembly in the present work was $95 \% \mathrm{NaCl}+5 \% \mathrm{NaF}$.

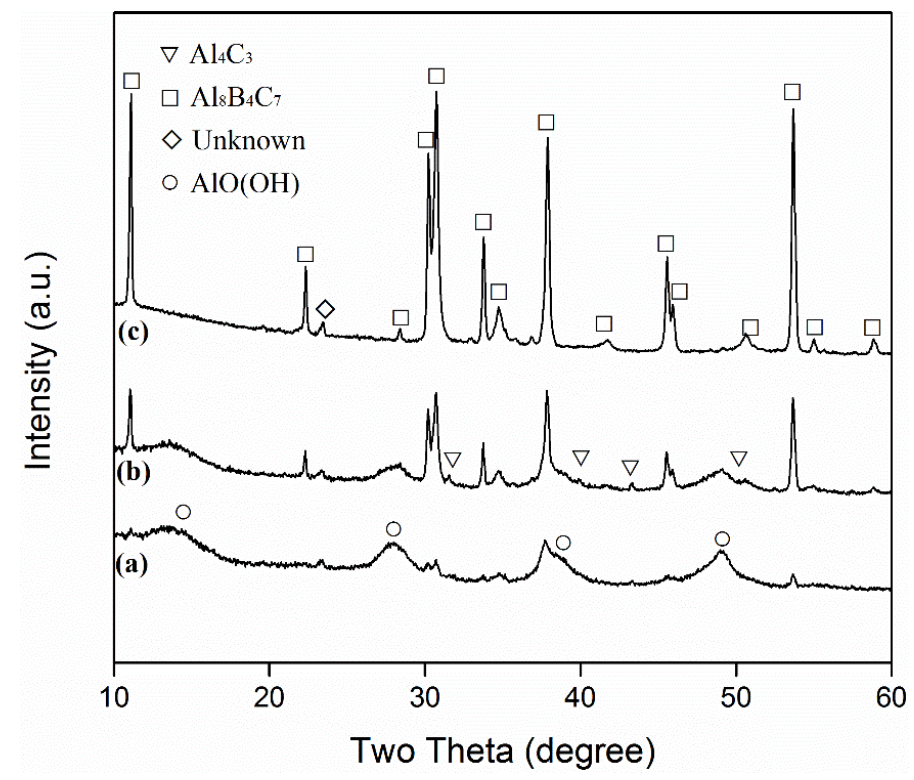

Figure 5. XRD patterns of samples resulting from $6 \mathrm{~h}$ of firing at $1250{ }^{\circ} \mathrm{C}$ in $20 \mathrm{~g}$ of (a) $\mathrm{NaCl}$, (b) $97.5 \% \mathrm{NaCl}+2.5 \% \mathrm{NaF}$, and (c) $95 \% \mathrm{NaCl}+5 \% \mathrm{NaF}$, respectively (after water washing).

\subsection{Microstructure of As-Prepared $A_{8} B_{4} C_{7}$ Powder}

Figure 6 presents SEM and TEM images of $\mathrm{Al}_{8} \mathrm{~B}_{4} \mathrm{C}_{7}$ particles synthesised in $95 \% \mathrm{NaCl}+5 \% \mathrm{NaF}$ at $1250{ }^{\circ} \mathrm{C}$ for $6 \mathrm{~h}$, revealing their irregular morphologies and average size of about $200 \mathrm{~nm}$. The particles overall were dispersed well, though some were agglomerated together. The average size of the particles was much smaller, and their dispersion was much better than it was when the conventional synthesis techniques were used [15-18]. The lattice interlayer spacing (one of the insets in Figure 6) was measured as around $0.29 \mathrm{~nm}$, which corresponds to the (111) plane of hexagonal $\mathrm{Al}_{8} \mathrm{~B}_{4} \mathrm{C}_{7}$. This, in addition to the selected area electron diffraction (SAED) pattern (the other inset in Figure 6) and the $X R D$ results in Figures 1 and 2, verified that the synthesised particles were $\mathrm{Al}_{8} \mathrm{~B}_{4} \mathrm{C}_{7}$.

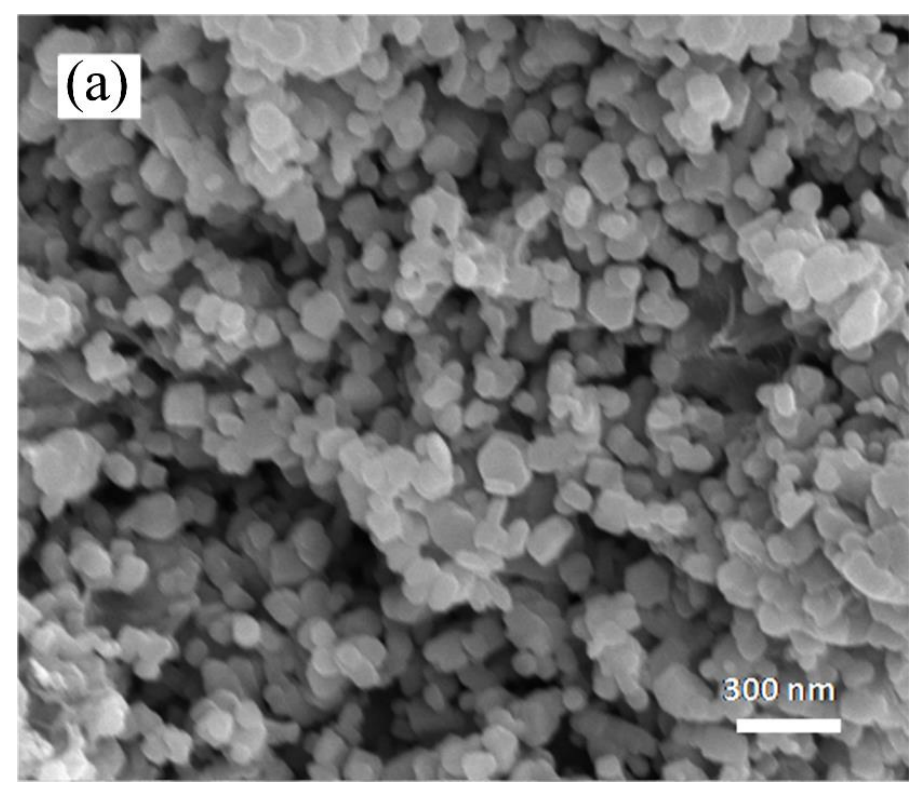

Figure 6. Cont. 


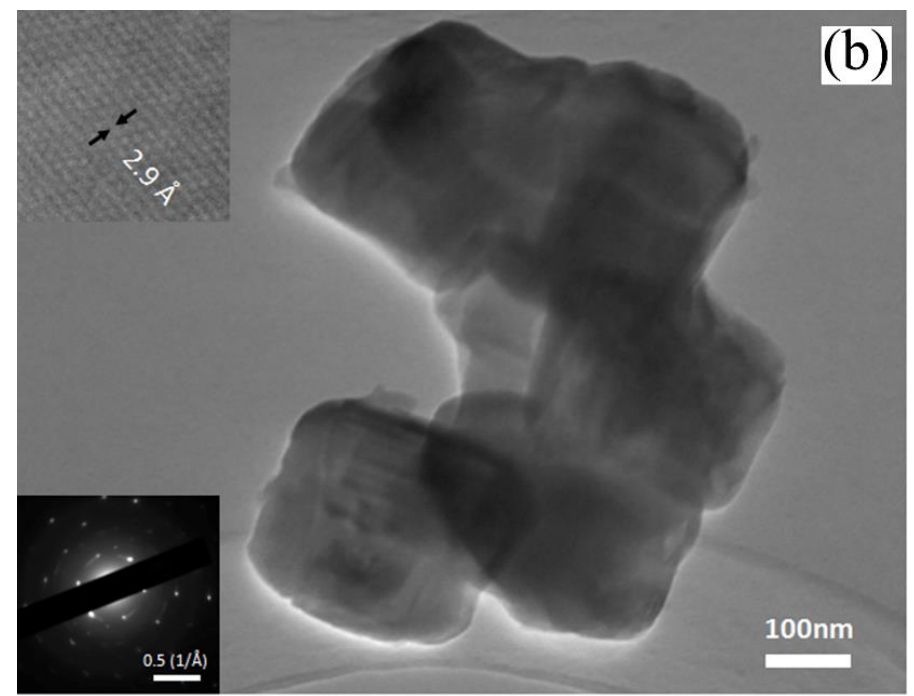

Figure 6. (a) SEM and (b) TEM images of $\mathrm{Al}_{8} \mathrm{~B}_{4} \mathrm{C}_{7}$ product powder prepared in $95 \% \mathrm{NaCl}+5 \% \mathrm{NaF}$ at $1250{ }^{\circ} \mathrm{C}$ for $6 \mathrm{~h}$.

\section{Further Discussion and Reaction/Synthesis Mechanisms}

Upon increasing the firing temperature above their melting/eutectic points, $\mathrm{NaCl}$ (melting point: $\sim 714^{\circ} \mathrm{C}$ ) and $\mathrm{NaF}$ (melting point: $\sim 743^{\circ} \mathrm{C}$ ) interacted with each other, forming a liquid medium in which $\mathrm{Al}$ slightly dissolved [26,27]. The dissolved $\mathrm{Al}$ diffused rapidly through the liquid medium onto the surfaces of $\mathrm{C}$ and $\mathrm{B}_{4} \mathrm{C}$, and then reacted with them to form $\mathrm{Al}_{4} \mathrm{C}_{3}$, and $\mathrm{Al}_{3} \mathrm{BC}+\mathrm{AlB}_{2}$, according to Equations (3) and (4), respectively.

$$
\begin{gathered}
4 \mathrm{Al}+3 \mathrm{C}=\mathrm{Al}_{4} \mathrm{C}_{3} \\
9 \mathrm{Al}+2 \mathrm{~B}_{4} \mathrm{C}=2 \mathrm{Al}_{3} \mathrm{BC}+3 \mathrm{AlB}_{2} \\
\mathrm{AlB}_{2}=\mathrm{Al}+2 \mathrm{~B}
\end{gathered}
$$

Since $\mathrm{AlB}_{2}$ is not thermodynamically stable at $>1000^{\circ} \mathrm{C}$ [28], the $\mathrm{AlB}_{2}$ formed from Equation (4) decomposed, forming $\mathrm{Al}$ and $\mathrm{B}$ (Equation (5)) in the molten salt [28]. The detection of $\mathrm{Al}_{4} \mathrm{C}_{3} / \mathrm{AlOOH}$ indicated the occurrence of Equation (3) at the test temperatures (Figures $1 \mathrm{a}-\mathrm{c}$ and $2 \mathrm{a}-\mathrm{C}$ ), and the detection of $\mathrm{Al}_{3} \mathrm{BC}$ and $\mathrm{AlB}_{2}$ in the $\mathrm{Al}-\mathrm{B}_{4} \mathrm{C}$ sample (Figure 3 ) indicated the occurrence of Equation (4). The $\mathrm{AlB}_{2}$ phase detected in this case is believed to be formed upon cooling from the Equation between the residual $\mathrm{Al}$ and $\mathrm{B}$ in the salt. The $\mathrm{B}$ formed from Equation (5) at the test temperatures also slightly dissolved in the molten salt $[29,30]$ and then diffused through the molten salt onto the surface of the $\mathrm{Al}_{4} \mathrm{C}_{3}$ formed from Equation (3), forming $\mathrm{Al}_{8} \mathrm{~B}_{4} \mathrm{C}_{7}$ according to Equation (6). As shown in Figure 4, $\mathrm{Al}_{8} \mathrm{~B}_{4} \mathrm{C}_{7}$ was formed in the fired $\mathrm{Al}_{4} \mathrm{C}_{3}-\mathrm{B}-\mathrm{C}$ sample, indicating that the original $\mathrm{Al}_{4} \mathrm{C}_{3}$ reacted directly with the $\mathrm{B}$ dissolved in the salt, to form $\mathrm{Al}_{8} \mathrm{~B}_{4} \mathrm{C}_{7}$.

$$
7 \mathrm{Al}_{4} \mathrm{C}_{3}+12[\mathrm{~B}]=3 \mathrm{Al}_{8} \mathrm{~B}_{4} \mathrm{C}_{7}+4[\mathrm{Al}]
$$

According to Figure $3 \mathrm{a}$, if no carbon was present, the intermediate $\mathrm{Al}_{3} \mathrm{BC}$ formed from Equation (4) appeared to be stable. However, when $C$ was present, it was readily converted into more stable $\mathrm{Al}_{8} \mathrm{~B}_{4} \mathrm{C}_{7}$ (Figure 4). This also explained why no $\mathrm{Al}_{3} \mathrm{BC}$ was found in the samples whose $\mathrm{XRD}$ patterns are shown in Figures 1 and 2. The mechanism by which it was transformed into $\mathrm{Al}_{8} \mathrm{~B}_{4} \mathrm{C}_{7}$ in the molten salt was not clear, but a plausible mechanism could be considered as follows: when $C$ was present, it reacted with the $\mathrm{Al}$ in the molten salt to form $\mathrm{Al}_{4} \mathrm{C}_{3}$, which further reacted with the $\mathrm{B}$ in the molten salt to 
form $\mathrm{Al}_{8} \mathrm{~B}_{4} \mathrm{C}_{7}$. The consumption of $\mathrm{Al}$ and $\mathrm{B}$ in the molten salt might have led to the decomposition of $\mathrm{Al}_{3} \mathrm{BC}$ and thus the additional formation of $\mathrm{Al}_{8} \mathrm{~B}_{4} \mathrm{C}_{7}$ according to Equation (7).

$$
7 \mathrm{Al}_{3} \mathrm{BC}=13[\mathrm{Al}]+\mathrm{Al}_{8} \mathrm{~B}_{4} \mathrm{C}_{7}+3[\mathrm{~B}]
$$

The overall reaction processes/mechanisms described above can also be used to explain the effects of firing temperature and salt type/assembly on the MSS process. With an increase in the firing temperature, the solubilities of $\mathrm{Al}$ and $\mathrm{B}$ in the molten salt were increased, and their diffusions in the molten salt accelerated. Consequently, Equations (3)-(7) were greatly facilitated. Therefore, the overall formation reaction (Equation (1)) was considerably accelerated (Figures 1-4). When a single salt of $\mathrm{NaCl}$ was used, there was only limited formation of $\mathrm{Al}_{8} \mathrm{~B}_{4} \mathrm{C}_{7}$ in the sample after $6 \mathrm{~h}$ of firing at $1250{ }^{\circ} \mathrm{C}$ (Figure 5a). However, when small amounts of $\mathrm{NaF}(2.5 \%)$ were added to $\mathrm{NaCl}$, much more $\mathrm{Al}_{8} \mathrm{~B}_{4} \mathrm{C}_{7}$ was formed (Figure $5 b$ ). Upon further increasing $\mathrm{NaF}$ to $5 \%$, the formation reaction was completed, and essentially phase-pure $\mathrm{Al}_{8} \mathrm{~B}_{4} \mathrm{C}_{7}$ was obtained (Figure $5 \mathrm{c}$ ). This can be explained as follows. $\mathrm{Al}$ and $\mathrm{B}$ have very limited solubility in molten $\mathrm{NaCl}$ [31], so Equations (3)-(7) proceeded very slowly in it. However, when $\mathrm{NaF}$ was added to $\mathrm{NaCl}$, the solubilities of $\mathrm{Al}$ and $\mathrm{B}$ in the binary salt were increased significantly, which led to great acceleration of Equations (3)-(7), i.e., the overall formation reaction (Equation (1)).

Thanks to the strong accelerating effect of the $\mathrm{NaCl}-\mathrm{NaF}$ binary salt discussed above, essentially phase-pure $\mathrm{Al}_{8} \mathrm{~B}_{4} \mathrm{C}_{7}$ particles were successfully prepared at $1250{ }^{\circ} \mathrm{C}$. This synthesis temperature was $350-550{ }^{\circ} \mathrm{C}$ lower than that required by the conventional synthesis routes [11,13-21], demonstrating the great advantage and feasibility of the MSS technique developed in this work.

\section{Conclusions}

A low-temperature molten salt synthesis technique was developed to synthesise high-quality $\mathrm{Al}_{8} \mathrm{~B}_{4} \mathrm{C}_{7}$ particles. The main conclusions can be drawn as follows.

1. $\mathrm{Al}_{8} \mathrm{~B}_{4} \mathrm{C}_{7}$ particles with an average size of about $200 \mathrm{~nm}$ were successfully synthesised after $6 \mathrm{~h}$ of firing in $\mathrm{NaCl}-\mathrm{NaF}$ at $1250^{\circ} \mathrm{C}$, from $\mathrm{Al}, \mathrm{B}_{4} \mathrm{C}$ and $\mathrm{C}$ starting powders. They were essentially phase-pure and generally well-dispersed.

2. Compared with the temperature required by a conventional synthesis technique, the synthesis temperature $\left(1250^{\circ} \mathrm{C}\right)$ in the present work was significantly lower $\left(350-500{ }^{\circ} \mathrm{C}\right.$ lower), owing to the great accelerating effect of $\mathrm{NaCl}-\mathrm{NaF}$ salt.

3. $\mathrm{Al}_{8} \mathrm{~B}_{4} \mathrm{C}_{7}$ particles were formed via the following mechanisms: at the test temperatures, $\mathrm{NaCl}$ and $\mathrm{NaF}$ interacted with each other, forming a liquid medium in which $\mathrm{Al}$ slightly dissolved. The dissolved $\mathrm{Al}$ diffused rapidly through the molten salt onto the surfaces of $\mathrm{C}$ and $\mathrm{B}_{4} \mathrm{C}$, reacting with them to form $\mathrm{Al}_{4} \mathrm{C}_{3}$, and $\mathrm{Al}_{3} \mathrm{BC}+\mathrm{AlB}_{2}$, respectively. $\mathrm{AlB}_{2}$ is not stable at $>1000^{\circ} \mathrm{C}$, so at the test temperatures, it decomposed into $\mathrm{B}$ and $\mathrm{Al}$. The newly formed $\mathrm{B}$ also slightly dissolved in the salt, diffused onto the surface of the $\mathrm{Al}_{4} \mathrm{C}_{3}$ formed earlier, and reacted with it to form $\mathrm{Al}_{8} \mathrm{~B}_{4} \mathrm{C}_{7}$, which consumed $\mathrm{Al}$ and $\mathrm{B}$ in the salt, making the $\mathrm{Al}_{3} \mathrm{BC}$ formed earlier decompose into additional $\mathrm{Al}_{8} \mathrm{~B}_{4} \mathrm{C}_{7}, \mathrm{Al}$ and $\mathrm{B}$.

Author Contributions: Experiment and initial draft: C.L.; conception and experiment design: B.C., X.L. and Q.J.; review and editing: S.Z., X.L. and Z.H.; supervision: S.Z. and B.C. All authors have read and agreed to the published version of the manuscript.

Funding: X.L., Q.J., Z.H. and B.C. would like to acknowledge the financial support from the State Key Laboratory of Refractories and Metallurgy (Wuhan University of Science and Technology), No. G201810, and visiting scholarships from China Scholarship Council.

Conflicts of Interest: The authors declare no conflict of interest. 


\section{References}

1. Wang, T.; Yamaguchi, A. Oxidation protection of $\mathrm{MgO}-\mathrm{C}$ refractories by means of $\mathrm{Al}_{8} \mathrm{~B}_{4} \mathrm{C}_{7}$. J. Am. Ceram. Soc. 2001, 84, 577-582. [CrossRef]

2. Wang, T.; Yamaguchi, A. Antioxidation behavior and effect of $\mathrm{ZrB}_{2}-\mathrm{Al}_{3} \mathrm{BC}_{3}$ composites prepared using $\mathrm{Al}-\mathrm{B}_{4} \mathrm{C}-\mathrm{C}$ additives and spark plasma sintering added to carbon-containing refractories. J. Ceram. Soc. Jpn. 2000, 108, 818-822. [CrossRef]

3. Yamaguchi, A.; Nakano, Y.; Wang, T. Effect and behaviour of Al-B-C system antioxidants added to MgO-C refractories. Can. Metall. Q. 2000, 39, 381-386. [CrossRef]

4. Zhang, S.; Marriott, N.J.; Lee, W.E. Thermochemistry and microstructures of MgO-C refractories containing various antioxidants. J. Eur. Ceram. Soc. 2000, 21, 1037-1047. [CrossRef]

5. Zhang, S.; Lee, W.E. Influence of additives on corrosion resistance and corroded microstructures of MgO-C refractories. J. Eur. Ceram. Soc. 2001, 21, 2393-2405. [CrossRef]

6. Lee, S.H.; Kim, B.N.; Tanaka, H. Low temperature sintering of nano-SiC using a novel $\mathrm{Al}_{8} \mathrm{~B}_{4} \mathrm{C}_{7}$ additive. J. Mater. Res. 2010, 25, 471-475. [CrossRef]

7. Lee, S.H.; Sakka, Y.; Tanaka, H.; Kagawa, Y. Wet Processing and low-temperature pressureless sintering of $\mathrm{SiC}$ using a novel $\mathrm{Al}_{3} \mathrm{BC}_{3}$ sintering additive. J. Am. Ceram. Soc. 2009, 92, 2888-2893. [CrossRef]

8. Wang, H.; Feng, L.; Lee, S.H.; Chen, J.; Fan, B.; Chen, D.; Lu, H.; Xu, H.; Zhang, R. $\mathrm{ZrB}_{2}-\mathrm{Al}_{3} \mathrm{BC}_{3}$ composites prepared using $\mathrm{Al}-\mathrm{B}_{4} \mathrm{C}-\mathrm{C}$ additives and spark plasma sintering. Ceram. Int. 2013, 39, 897-901. [CrossRef]

9. Jung, J.Y.; Jung, S.H.; Oh, H.C.; Lee, S.H.; Choi, S.C. Spark plasma sintering of $\mathrm{ZrB}_{2}$ using $\mathrm{Al}_{3} \mathrm{BC}_{3}$ as an additive. J. Ceram. Process. Res. 2012, 13, 641-645.

10. Da Rocha, R.M.; de Melo, F.C.L. Sintering of $\mathrm{B}_{4} \mathrm{C}$ by pressureless liquid phase sintering. Mater. Sci. Forum 2010, 660, 170-175. [CrossRef]

11. Li, F.; Zhou, Y.; He, L.; Liu, B.; Wang, J. Synthesis, microstructure, and mechanical properties of $\mathrm{Al}_{3} \mathrm{BC}_{3}$. J. Am. Ceram. Soc. 2008, 91, 2343-2348. [CrossRef]

12. Wang, T.; Yamaguchi, A. Some properties of sintered $\mathrm{Al}_{8} \mathrm{~B}_{4} \mathrm{C}_{7}$. J. Mater. Sci. Lett. 2000, 19, $1045-1046$. [CrossRef]

13. Wang, T.; Yamaguchi, A. Synthesis of $\mathrm{Al}_{8} \mathrm{~B}_{4} \mathrm{C}_{7}$ and its oxidation properties in air. J. Ceram. Soc. Jpn. 2000, 108, 375-380. [CrossRef]

14. Hashimoto, S.; Ishihara, T.; Inoue, K.; Honda, S.; Iwamoto, Y.; Zhang, S. Synthesis and mechanical properties of $\mathrm{Al}_{8} \mathrm{~B}_{4} \mathrm{C}_{7}$. J. Ceram. Soc. Jpn. 2009, 117, 18-21. [CrossRef]

15. Zhu, H.; Pan, C.; Deng, C.; Yuan, W. Preparation of $\mathrm{Al}_{8} \mathrm{~B}_{4} \mathrm{C}_{7}$ composite materials by using oxide raw materials. IOP Conf. Ser. Mater. Sci. Eng. 2011, 18, 222008. [CrossRef]

16. Deng, C.; Zhou, W.; Zhu, H.; Yu, Y. Synthesis of $\mathrm{Al}_{8} \mathrm{~B}_{4} \mathrm{C}_{7}$ from $\mathrm{Al} / \mathrm{Na}_{2} \mathrm{~B}_{4} \mathrm{O}_{7} \cdot 10 \mathrm{H}_{2} \mathrm{O} / \mathrm{C}$ Mixed Powders. Adv. Mater. Res. 2009, 79, 1375-1378. [CrossRef]

17. Cui, P.; Yuan, W.; Deng, C.; Zhu, H.; Li, J. Synthesis of $\mathrm{Al}_{8} \mathrm{~B}_{4} \mathrm{C}_{7}$ from Aluminum, Boron Trioxide and Activated Carbon Mixed Powders. Adv. Mater. Res. 2013, 634, 2383-2387. [CrossRef]

18. Lee, S.H.; Yin, J.; Feng, L.; Lee, J.S. Synthesis of $\mathrm{Al}_{3} \mathrm{BC}_{3}$ particulates by carbo-thermal reduction process-Parameter optimization and mechanism analysis. J. Ceram. Soc. Jpn. 2014, 122, 772-776. [CrossRef]

19. Lee, S.H.; Kim, H.D.; Choi, S.C.; Nishimura, T.; Lee, J.S.; Tanaka, H. Chemical composition and microstructure of $\mathrm{Al}_{3} \mathrm{BC}_{3}$ prepared by different densification methods. J. Eur. Ceram. Soc. 2010, 30, 1015-1020. [CrossRef]

20. Che, Q.; Ma, Q.; Lu, J. Fabrication of $\mathrm{Al}_{3} \mathrm{BC}_{3}$-based porous ceramics by pressureless sintering. Adv. Mater. Res. 2012, 412, 340-343. [CrossRef]

21. Gao, Y.; Huang, Z.; Fang, M.; Liu, Y.; Huang, S.; Ouyang, X. Synthesis of $\mathrm{Al}_{8} \mathrm{~B}_{4} \mathrm{C}_{7}$ ceramic powder from $\mathrm{Al} / \mathrm{B}_{4} \mathrm{C} / \mathrm{C}$ mixtures. Powder Technol. 2012, 226, 269-273. [CrossRef]

22. Inoue, Z.; Tanaka, H.; Inomata, Y. Synthesis and X-ray crystallography of aluminium boron carbide, $\mathrm{Al}_{8} \mathrm{~B}_{4} \mathrm{C}_{7}$. J. Mater. Sci. 1980, 15, 3036-3040. [CrossRef]

23. Li, Z.; Zhang, S.; Lee, W.E. Molten salt synthesis of $\mathrm{LaAlO}_{3}$ powder at low temperatures. J. Eur. Ceram. Soc. 2007, 27, 3201-3205. [CrossRef]

24. Jayaseelan, D.D.; Zhang, S.; Hashimoto, S.; Lee, W.E. Template formation of magnesium aluminate $\left(\mathrm{MgAl}_{2} \mathrm{O}_{4}\right)$ spinel microplatelets in molten salt. J. Eur. Ceram. Soc. 2007, 27, 4745-4749. [CrossRef] 
25. Xie, W.; Möbus, G.; Zhang, S. Molten salt synthesis of silicon carbide nanorods using carbon nanotubes as templates. J. Mater. Chem. 2011, 21, 18325. [CrossRef]

26. Yoshida, K.; Dewing, E.W. The Solubility of Aluminum in Cryolite Melts. Essential Readings in Light Metals: Aluminum Reduction Technology; John Wiley \& Sons Inc.: Hoboken, NJ, USA, 2016; pp. 12-18.

27. Yoshida, K.; Dewing, E.W. The apparent solubility of aluminum in cryolite melts. Metall. Mater. Trans. 1972, 3, 1817-1821. [CrossRef]

28. Ren, D.; Deng, Q.; Wang, J.; Li, Y.; Li, M.; Ran, S.; Du, S.; Huang, Q. Densification and mechanical properties of pulsed electric current sintered $\mathrm{B}_{4} \mathrm{C}$ with in situ synthesized $\mathrm{Al}_{3} \mathrm{BC}$ obtained by the molten-salt method. J. Eur. Ceram. Soc. 2017, 37, 4524-4531. [CrossRef]

29. Bao, K.; Wen, Y.; Khangkhamano, M.; Zhang, S. Low-temperature preparation of titanium diboride fine powder via magnesiothermic reduction in molten salt. J. Am. Ceram. Soc. 2017, 100, 2266-2272. [CrossRef]

30. Zhang, S.; Khangkhamano, M.; Zhang, H.; Yeprem, H.A. Novel Synthesis of $\mathrm{ZrB}_{2}$ Powder Via Molten-Salt-Mediated Magnesiothermic Reduction. J. Am. Ceram. Soc. 2014, 97, 1686-1688. [CrossRef]

31. Viala, J.C.; Bouix, J.; Gonzalez, G.; Esnouf, C. Chemical reactivity of aluminium with boron carbide. J. Mater. Sci. 1997, 32, 4559-4573. [CrossRef]

(C) 2019 by the authors. Licensee MDPI, Basel, Switzerland. This article is an open access article distributed under the terms and conditions of the Creative Commons Attribution (CC BY) license (http://creativecommons.org/licenses/by/4.0/). 